\title{
THE HIGHER EDUCATION AND SALARIES
}

\begin{abstract}
Education is vital for dynamic growth and development. The higher education is important for every country. It is regulated by systemic regulations and bylaws. In this paper, the interest is directed at the salaries of employees in the state higher education, given their long-standing lag. The forms of payment of employees are analyzed and the salary level is compared with the averages in the country. The paper proposes solutions that are of importance for this issue, especially for forming a payroll model that will correspond to the meaning of the educational segment of the society. The status of the professors as service providers is inadequate and is not regulated from the aspect of the salaries and the benefits for the invested labour. Without motivated teachers and professors who implement the higher education system, changes and results cannot be expected in terms of the quality of human resources produced at universities. In the absence of a culture of appreciation of the knowledge, postulates are formed which in the long run cannot change the values of the systems in society.
\end{abstract}

Keywords: HIGHER EDUCATION, SALARIES, REGULATION, PERCEPTION, OPPORTUNITIES

\section{Introduction}

The payment of work engagement is of exceptional importance in any organized structure. The motivation for working engagement and the behaviour of the employees, in order to equate them with the goals, mission and vision of the organization, are directly related to the payment of their engagement, that is, to the accomplished work and the tasks that have been set.

Management of the organization is not possible if the salary segment is not managed as an integral part of the management functions in the organization. The salary is important for every employee and the feedback effect, and the achieved results and the success as a whole depend on the properly set payment system.

The perception of the value system varies considerably if there are variations in the payment systems. This in turn affects the motivation and the level of engagement in achieving the goals of the organization. Due to the complexity of the establishment and the application of the payment systems and the impact they have, it is necessary to pay constant attention and monitor the salaries of the employees. This would 
avoid negative tendencies such as decrease in the quality of the execution of the tasks and the outflow of personnel in sectors where payment is based on higher standards and assessments of the engagement.

The higher education as a segment in the education system in the country in terms of salaries has an inadequately built system and a long-term tendency for lagging in the amount of salaries. Therefore, there are demands and tendencies for changing the approach to salaries formation in higher education, which is elaborated in this paper.

\section{Higher education and perception}

In the Republic of Macedonia, there is a positive perception of education as a basis for engagement of the working-age population. Trained individuals open up micro, small and medium size enterprises and are active in the economy and in the services domain. Knowledge is outdated and should be innovated through education by investing, innovating and motivating.

The main motivating factor for inclusion in the educational process in our country is still unemployment, especially among young people. Therefore, the search for new opportunities and conditions according to the degree of development of the state is aimed at motivating people to educate themselves about employment and selfemployment.

"Higher education is realized at three levels: undergraduate, master and doctoral studies. There are six state universities (two of them in Albanian), one privatepublic university, nine private universities and two high schools. In the academic year 2016/2017, about 58,000 undergraduate students enrolled at 122 faculties within the universities, and about $56 \%$ of them were females. The gross inclusion rate was $34.2 \%$ (39.2\% for females), and the net rate was $26.3 \%$ (31\% for females). In 2015/16, there were 3,034 postgraduate students and $58,9 \%$ of them studied at state universities $(\mathrm{MOH}$, Стратегија за образованието за 2018-2025 година и Акциски план, 2017).

It can be perceived that this is a well-formed educational structure and a system that produces highly educated citizens, and thus creates added value in society. With the offered programs, the wide range of coverage of the generations, the dispersion and the availability of studies, excellent opportunities are offered. But all this should also be reviewed from the point of view of the holders of the educational activity that are the professors and teaching staff employed at the universities, faculties, institutes and other higher education institutions.

\section{Employment and wages in higher education}

The number of teachers and associates in all higher education institutions in the Republic of Macedonia in the academic year 2016/17 was 4.114. Of the total number 
of teachers and associates, 2,923 or $71.1 \%$ were teachers, and 1.191, i.e., $28.9 \%$ were associates or teaching staff (Државен завод за статистика, Наставници и соработници во високообразовните установи, 2018). Out of 4.114 teachers and associates at private universities, 513 teachers and 182 associates, or 695 persons in total, were employed, or $16.9 \%$ of the universities' staff.

This means that 2.410 teachers or $82.5 \%$ of the total number of teachers were employed at state universities, while $17.5 \%$ of the number of teachers were employed in the private sector. Of the associates in the teaching sector, 1.009, or $74.7 \%$, worked at state universities, while 182 persons or $15.3 \%$ were employed at private universities.

In the academic year 2016/17, in the first cycle of studies, 58.083 students were enrolled in all higher education institutions (Државен завод за статистика, Запишани студенти на високите стручни школи и факултетите, 2018).

These data present the staff structure of higher education institutions that has been shaped for years, the reason why funds, efforts and energy, which are not appropriately rewarded, are invested. Namely, if a comparison between the salaries of the employees of state universities with the salaries of other professions in the country is made one can perceive a very unfavourable situation for the university staff. The salaries of collaborators are particularly disadvantageous, which leads to the loosing of interest in creating new teaching staff and rejuvenating the higher education institutions. This lagging became more pronounced after the introduction of the concept of gross salary.

On this basis, the following gross amounts are paid for the employees of the state universities in the state Budget (Министерство за финансии, Дополнет предлог буџет на PМ за 2018, 2017), and after the deduction of the compulsory contributions and tax, the following net amounts are paid.

\begin{tabular}{|c|c|c|c|c|c|c|}
\hline Title & $\begin{array}{c}\text { Amount of } \\
\text { the gross } \\
\text { salary } \\
\text { from the } \\
\text { Ministry of } \\
\text { Education } \\
\text { and Sci- } \\
\text { ence }\end{array}$ & $\begin{array}{c}\text { Amount of } \\
\text { the paid } \\
\text { salary at }\end{array}$ & $\begin{array}{c}\text { Average sa- } \\
\text { lary in the } \\
\text { Republic of } \\
\text { Macedonia } \\
\text { in January } \\
\text { and } \\
\text { February } \\
\mathbf{2 0 1 8}\end{array}$ & $\begin{array}{c}\text { Average } \\
\text { salary in } \\
\text { education } \\
\text { in RM } \\
\text { January } \\
\text { and } \\
\text { February } \\
\mathbf{2 0 1 8}\end{array}$ & $\begin{array}{c}\text { Coefficient } \\
3: 4\end{array}$ & $\begin{array}{c}\text { \% of Differ- } \\
\text { ence4:5 }\end{array}$ \\
\hline $\mathbf{1}$ & $\mathbf{2}$ & $\mathbf{3}$ & $\mathbf{4}$ & $\mathbf{5}$ & $\mathbf{6}$ & \\
\hline $\begin{array}{c}\text { Assistant } \\
\text { professor }\end{array}$ & 44.184 & 29.783 & & & & \\
\hline $\begin{array}{c}\text { Associate } \\
\text { Professor }\end{array}$ & 46.534 & 31.326 & & & & \\
\hline $\begin{array}{c}\text { Full-time } \\
\text { professor }\end{array}$ & 51.310 & 34.463 & & & & \\
\hline & Average & 31.857 & 23.589 & 23.032 & 1,350 & $1,024(-2,4)$ \\
\hline
\end{tabular}


Compared to the average net salary paid in the Republic of Macedonia at February 2018 (last available data in the writing of this paper, according to State Statistical Office) it can be concluded that the average salaries of the teachers in higher education in relation to the average net salary in the country are increased by 35\%. This can create the wrong conclusion that salaries are one third above average and are relatively high. According to the data published by the Unions for an average four-member family the costs of living take an average monthly amount of 32.418 Macedonian denars. This means that the wages that are subject to analysis are approaching the necessary minimum and cannot be estimated as high salaries; on the contrary, they are low and insufficient. Of course, here we should compare the level of education, that is, whether it is a $\mathrm{PhD}$, and whether they are selected according to a special law that provides additional conditions and criteria for their employment. No university professor can be elected for a position if he does not meet the legal criteria. In contrast, higher education staff is required to have a minimum of 240 ECTS credits, and even less, if they are advisers in individual state institutions or bodies, they can get a salary of over 50.000 Macedonian denars. Or, for comparison, a state advisor at the Ministry of education and science with 240 credits has a basic salary of 36.881 denars (Министерство за образование и наука. Интерен оглас број 03/2018 за унапредување на административни службеници, 2018) or higher than a university professor by $16 \%$. It shows how much the labour and salaries of university professors are underestimated and that the institution in which the individual is employed is the most important one.

Each unit or faculty or university can add a certain amount on the paid net amounts, depending on the revenues it incurs, ranging from 5 to 10 thousand Macedonian denars depending on the title, the seniority, etc. With these additions, which are variable wages, they are significantly lower in terms of paid salaries in other sectors and activities, as well as in the countries of the region, and cannot be compared with the wages in EU countries or wider.

The salaries seriously lag behind with this addition, especially in relation to those employed in the public sector and in the state administration, especially if the level of education and the achieved level of titles in higher education are compared.

Also, the amount of funds intended for salaries for higher education in the Budget of the state is reduced, and it does not allow the recruitment of staff for the purpose of replacing the emptied positions after people retire.

\section{Salaries and outflow of staff}

In the study "Establishing criteria for quality in social sciences in the function of preventing brain drain from the Republic of Macedonia"' it is indicated that two thirds or $69 \%$ of university professors want to leave the country. The reasons are diffe-

\footnotetext{
${ }^{1}$ Conducted by Institute for Strategic Research and Education, Skopje, 2017
} 
rent, but the brain drains are basically based on the working conditions and the low salaries of university professors.

Most often, the professions demanded on the job market are emigrated in highly developed countries, in the European countries and the United States. The educated persons look for better opportunities for their own development and work, but also, of course, for higher salaries, whereby their position and acquired knowledge are really valued. In other words, they go where their knowledge and work are valued higher according to the labour invested in them, their education, postgraduate and doctoral titles, which are not considered in our society adequately within the social frames and in the terms of the added value that they create.

The insufficient separation of science and education gives negative results and, among other things, is expressed through the outflow of educated persons. The migration flows are unfavourable and in the long run lead to a slowdown in the socioeconomic development of the country, given that the most educated cadres do not perceive their perspective in the country. The government does not build a strategy, nor does it try to motivate these thinking minds to remain in the state and to acquire success in areas for which they have been trained or specialized. Thus, the funds invested in such staff are lost irreversibly, the resources of the state and society are lost, and their compensation is uncertain and long-lasting. In contrast, the countries in which these people emigrate receive highly profiled personnel without even investing in them.

The funds that are intended for investments in education, specialization, doctorates and writing and publishing papers abroad, which are paid from personal funds, cannot be compensated and recovered as an investment from the salaries received by university professors. What is the logic in passing the most creative period of the individual under conditions of limits that are administratively established without seeing the consequences of it? The existential conditions are created, they are systemic and programmatic, and are shaped and changed, and in their absence the decision to emigrate in other environments with different perception and treatment of these cadres is easily adopted. In the absence of measurable criteria for evaluating these cadres, the subjectivism and political eligibility became dominant, which created a total dissatisfaction and a mental repulsion as a punitive effect.

\section{The system and wages}

The Constitution of the Republic of Macedonia stipulates in Article 32 that: "Everyone has the right to work, free choice of employment, protection at work and material security during the temporary unemployment ... Every employee has the right to adequate earnings .... The exercise of the rights of employees and their position are regulated by law and by collective agreements" (Устав на P.M., Art. 32).

The Law on Public Sector Employees, which includes the teaching staff of higher education in Article 25, states that: "Public sector employees are entitled to a salary 
for their work in accordance with special laws, general labour regulations and collective agreements" (Закон за вработените во јавниот сектор, Art. 25).

It follows from this that the issue of salaries for employees in the higher education in accordance with the Constitution and the cited law should be regulated systematically or by law. This has not been done in the past years nor is it defined by the new Law on Higher Education adopted on May 2, 2018. A collective agreement on higher education has not been formulated, and there is no union organization that would influence social dialogue and salaries in the area of higher education.

In the Law on Public Service Providers, professors and associate professors at state universities are in accordance with the existing regulations determined for service providers. For most employees, this category is not clear and it is right to require education in order to have a separate treatment.

The Public Sector Jobs Catalogue (Министерство за информатичко општество и администрација, Каталогот на работни места во јавниот сектор, 2018) version 8.0 foresees that a faculty professor needs a minimum of 240 credits. The Law on Higher Education obligatory requires the professor to have a $\mathrm{PhD}$, and to have earned 480 ECTS credits. Such disagreement is perceived in other professions (a doctor of medicine or dentistry is required to have 240 credits for employment, and this profile acquires 300 credits with graduation). This indicates that there are systematic inconsistencies, but with this determination of a minimum level of education (240 credits for a university professor), a lower coefficient for calculation of the amount envisaged for the gross and net salary of the university staff and less payment in the budgets of universities is provided.

The Education Strategy for 2018-2025 and the Action Plan do not address the issue of salaries of employees in education. This means that by 2025 the education sector will see no changes in terms of labour interest for higher salaries and a better standard of employees. Individual changes occur annually, but not within a medium and long-term strategy that will enable education in general, and in this context higher education will provide its place and role in the social structure.

From the abovementioned it can be assessed that changes are necessary in the system of salaries for university professors and it should be harmonized with the Constitution, the laws, as well as the decisions pertaining to managerial workers in the state bodies.

\section{Construction of a new system of salaries}

The educational situation was made with observations and research, but there was no analysis of the situation with regard to the incomes in education and especially with regard to the salaries of the employees in the higher education. The salaries of employees in the Law on Higher Education are not subject to regulation and from there it will be necessary to resolve this issue by making urgent changes in the law. The sys- 
tem law on this profile puts university professors and other higher education institutions on the margins of the higher education process. They are degraded with frozen salaries for many years.

From there, a solving solution proposed by the Professorial Plenum in a public debate during 2017 and 2018 was to recognize the costs per student and on that basis to recognize the income that one teacher in higher education would have to receive as compensation from the state. It was also proposed to adopt a Methodology for determining the prise and the cost of a study place in order to determine the basic salary of the holders of the higher education activity. The proposal did not enter into a public hearing and was not adopted.

An opinion was also offered in the public hearing procedure with a decision proposing that the basic salary of the professors employed in the higher education is harmonized at the level of the average salary paid in the country in the previous year.

According to the existing legal decisions on salaries of elected and appointed officials and managerial workers, the following is determined: "The funds for the salary of officials and managerial workers are provided with the budget of the Republic. The salary of an official and a managerial worker is determined in such a way that the basis for calculating the salary is multiplied by the determined coefficient and increases by the percentage of the work experience. The basis for calculating the salary is the average monthly salary paid per employee in the Republic for the previous year, according to the data of the State Statistical Office. The coefficients for determining the salary and salary compensation are from 2.20 to 4.50."

According to the abovementioned, the same solution can be determined, whereby the basic salary of the professors in higher education should be determined according to the average salary paid in the previous year determined by the State Statistical Office and multiplied by the coefficient of 2.6 to 2.9 according to the professor's title.

The amounts of personal income can be used to improve the activity and raise the quality of work and the working conditions of the employee. The higher education institution can independently dispose of them, in accordance with the law and the general acts of the higher education institution.

During the process of adopting the Law on Higher Education in the Assembly of the Republic of Macedonia, several amendments were proposed, but no amendments were adopted, and among them were the amendments regarding the amount of wages. It was suggested that the net salary of a junior teaching assistant on a faculty is equal to one and a half net salaries paid in the Republic of Macedonia in the previous year, while the net salary of the assistant should be equal to three average net salaries. It was also proposed that the net salary of an assistant professor is in the amount of four average net salaries, that the net salary of an associate professor should be four and a half, and that the net salary of a full professor should be in the amount of five average net salaries paid in the last year in the Republic of Macedonia. These proposals have not be- 
en adopted, that is, the Law on Higher Education has not accepted the issue of salaries to be subject to regulation.

\section{Conclusion}

The salaries are a very sensitive aspect of the arrangement of relations, especially in the segment of state universities where the majority of the educated people in the country work. Without developing and building stimulus tools that will enable the functioning of the system of higher education and adequate salaries for staff, assistants professors, associate professors and full time professors, progress cannot be expected in the field of higher education.

Also, without establishing a systemic guarantee for employees in the higher education sector at the state universities that are dominant in the educational process, no changes that will bring European and world level education can be expected.

In the absence of a positive approach to the personnel of state universities separately from the aspect of salaries, negative tendencies, outflow of personnel and other negatives are possible, as indicated in the paper.

The educational system that enhances the ability of individuals to acquire professional knowledge that is needed and demanded by the market must be put into function for raising social actions and changing the perception for the needs of the staff from state universities. 


\section{References}

Државен завод за статистика. (2018). Насииавници и сорабойници во високообразов-

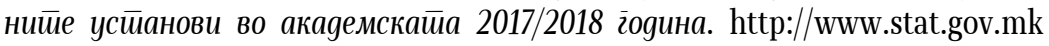
/Publikacii/1.2.18.04_mk.pdf (Accessed: 06.05.2018)

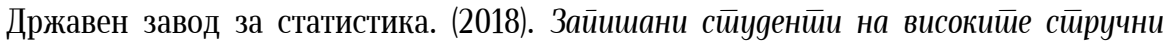

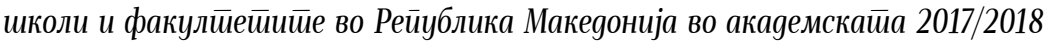
гоgина (иррв циклус на стйуии). http://www.stat.gov.mk/PrikaziSoopstenie. aspx?rbrtxt=29 (Accessed: 07.05.2018)

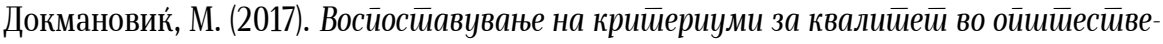

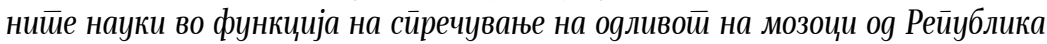
Макеgонија. Скопје: Институт за стратешки истражувања и едукација.

Закон за вработените во јавниот сектор, консолидиран текст. (2018). Службен весник на Рейублика Макеgонија. број 27/2014, 199/2014, 27/2016 и 35/2018.

Министерство за финансии на РМ. (2017). Дойолнеие йреgлог̄ буцей на РМ за 2018. https://finance.gov.mk/files/u6/BUDZET\%202018\%20\%20DOPOLNET\%20PRED LOG\%20(12.12.2017).pdf (Accessed: 08.05.2018)

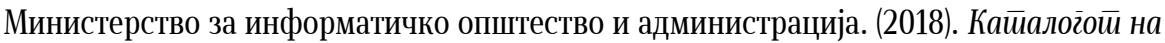

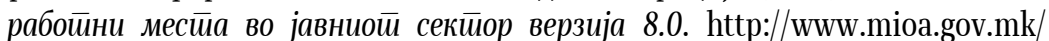
files/dokumenti/KATALOG_NA_RABOTNI_MESTA_21012016_v8.pdf (Accessed: 09.05.2018)

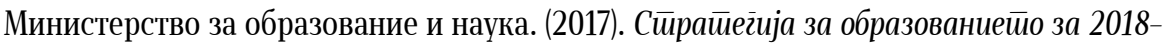
2025 гоgина и Акииски йлан.

Министерство за образование и наука. (2018). Инйерен ог̆лас број 03/2018 за унайре-

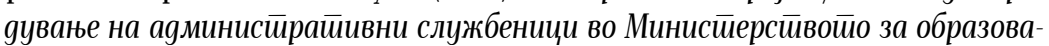
ние и наука. http://www.mon.gov.mk/index.php/2014-07-23-14-03-24/vesti-i-na stani/2376-03-2018 (Accessed: 06.05.2018)

Министерство за образование и наука. (2018). Закон за високойо образование. Собрание на РМ од 2 мај 2018.

Прирачник за йроцена на влијаниейо на реїулайивайа, Regulatory Impact Assessment - RIA. Влада на Република Македонија, Скопје, 2009.

усйав на Рейублика Макеgонија 